\title{
BARRIERS FOR SHANGHAI COOPERATION ORGANIZATION (SCO) TO PAVE ROAD TO SUPRANATIONALISM
}

\author{
Mahbi Maulaya \\ Universitas Muhammadiyah Yogyakarta; Indonesia: maulayamahbi@gmail.com
}

\begin{abstract}
Abstrak
Studi ini dilakukan dengan berlandaskan dua pertanyaan yang hadir di tengah perkembangan Shanghai Cooperation Organization (SCO) yang cukup signifikan. Dua pertanyaan tersebut ialah; 1.) Mampukah SCO meningkatkan kapabilitas dan kompetensinya sebagai organisasi regional dengan menjadi organisasi supranasional? 2. Dapatkah SCO memasukkan norma dan nilai supranasionalisme ke dalam mekanismenya? Dalam upaya untuk menjawab kedua pertanyaan tersebut, studi ini menelusuri gagasan dasar dari konsep supranasionalisme dan menerapkan metode penelitian kualitatif dan metode penelitian pustaka, Studi ini menjelaskan bahwa SCO tidak memiliki landasan yang kuat untuk memiliki kapasitas supranasionalisme. Argumen tersebut bersumber dari fakta bahwa SCO adalah agen/institusi yang dirancang untuk menjaga kedaulatan anggotanya dan juga organisasi tersebut memiliki anggota dengan kultur hegemonik dan nasionalisme yang kuat.
\end{abstract}

Kata Kunci: Asia Tengah, kedaulatan, nasionalisme, Shanghai Cooperation Organization (SCO), supranationalisme

\begin{abstract}
This study was conducted based on two questions that were present in the midst of the significant development of the Shanghai Cooperation Organization (SCO). The two questions are; 1.) Can SCO increase its capability and competence as a regional organization by becoming a supranational organization? 2. Can SCO incorporate the norms and values of supranationalism into its mechanism? In the effort to answer these two questions, this study explores the basic ideas of supranationalism and applies qualitative research methods and literature research methods. This study explains that SCO does not have a solid foundation to have the capacity of supranationalism. This argument originates from the fact that SCO is an agency/institution designed to safeguard the sovereignty of its members and also that the organization has members with a strong hegemonic culture and nationalism.
\end{abstract}

Keywords: Central Asia, Nationalism, Shanghai Cooperation Organization (SCO), sovereignty, supranationalism 


\section{Introduction}

Central Asia is one among other regions that provide room for and opt to endorse regional cooperation. In the range of the eighteenth and nineteenth centuries, the Tsarist empire conquered the whole region after overpowering British dominance in the so-called 'Great Game'. The Tsar did not create central control over the region but rather to maintain a traditional form of government, as long as political stability remains to exist. Standing in a converse position, the Soviet Union laid down a more incisive control during 1924-1936 (Menon \& Spruyt, 1999). Stalin made the nowadays border in Central Asia. He created precise borders that were not 'national' but based on an artificial titular ethnic majority. Following the Soviet Union's dissolution in the 1990s, Central Asia was filled with a nuance of tension. Since the shadows of Moscow has been abolished, five Central Asian republics became independent nation-states. However, it led to the reemergence of rivalries and inter-ethnic discord among them (Di Placido, 2007). The heat of the Central Asia atmosphere also upsurged due to China and the former Soviet Republics had unresolved border dispute. To deal with this situation, they carried out a series of bilateral and multilateral negotiations that disembogue to the forum of Shanghai Five establishment in 1996, an early episode for Central Asia's regionalization.

Compared to what other regions have done (Europe with European Coal and Steel Community in 1952 and Southeast Asia with Association of Southeast Asian Nations in 1967), Central Asia's regionalization process is relatively a recent phenomenon. The forum of Shanghai Five was held on 26 April 1996 by the attendance of China, Kazakhstan, Kyrgyzstan, Russia, and Tajikistan. The negotiation then gave birth to the Shanghai Agreement, which resides in the five countries' commitment to enhancing mutual confidence in military-related relations across border areas. This meeting became an essential historical stage in constructing the identity of the Shanghai Five. Afterward, the meeting has been held annually and developed into a substantial practice for each of the five countries.

The Shanghai Five represents a new global aim regarding security-related activities consisting of the value of mutual trust, disarmament, and a new type of interstate relations. The arrival of progressive economic globalization and the rapidly swelling number of terrorism activities and separatist movements demanded Central Asia to develop a self-economy and provide regional security. Thus, the fifth anniversary of Shanghai Five on 15 June 2001 was functioned by the head of Shanghai Five and President of the Republic of Uzbekistan (who previously invited as 
a guest participant in the 2000 Dushanbe Meeting) to fuse their approval in enhancing the degree of Shanghai Five into a higher level. It was a motion to make their community acquire significant influence and support in developing a new dimension of cooperation for them. As a result of this pledge, the six countries signed the Declaration on the Establishment of the Shanghai Cooperation Organization, the first chapter of the SCO story (Haq \& Mughal, 2007).

Under the SCO scenario, the kinds of topics that were brought to the negotiation table blossomed to a great extent. This progress is divided by Marcel de Haas and Frans-Paul van der Putten into three phases. In the first phase (1996-2001), when the six countries still worked under the shade of the newly-minted Shanghai Five, the discussion topic reasonably focus on confidence and security-building measures. In the second phase (2001-2004), after SCO saw the light of embodiment, the cooperation scope transcended into the amalgam of several issues. At that time, military tensions, or, might be labeled as the external threats, among those countries has been abolished. Nevertheless, parallel fate did not occur to internal threats. The six countries were then more likely to make SCO a platform for discussing terrorism, separatism, and extremism, the potential domestic-level threats later stamped as the 'Three Evils'. In the third phase (2004-2007), SCO began to mature in nature, having the capacity to become a comprehensive international organization, whereby its cooperation area spills over to immense space; economic, culture, resources, etc. (de Haas \& der Putten, 2007).

Since it has a high level of solvability in grappling with security-related issues, SCO intended to broaden its cooperation agenda. In 2005, when SCO leaders held a meeting in Astana, they endorsed the practice of Action Plan on Fulfillment of the Program of Multilateral Trade and Economic Cooperation, a framework to harbor better cooperation in trade, transportation, environmental protection, disaster relief, and the rational use of natural resources. In the 2006 meeting in Shanghai, SCO leaders tried to enlarge their organization's capacity to collaborate in energy, information technology, and transportation field, as the priority areas for further economic cooperation (Guang, 2011).

To this date, SCO's economic agenda has grown by leaps and bounds. The formation of a Business Council to provide room for investments in the regional project can be one instance. SCO's Business Council aims to warm up a cross-regional business framework. The plan for achieving this is by promoting and bolstering start-ups and humanitarian projects. A wide variety of construction projects have been arranged to advocate economic prosperity and boost 
connectivity in the region, such as the construction of transport infrastructure, highways and railways, and oil and gas pipelines (Akram, 2020).

In the cultural dimension, SCO is committed to cooperating in education, sports, tourism, and other cultural endeavors. This pledge was manifested by the 16th Meeting of the Ministers of Culture of SCO's member states on 15 May 2019. In this event, not only did it enhance and strengthen their engagement in cultural-related cooperation, but SCO member states also acknowledged the Kyrgyz side's report about the possibility of holding the Silk Road Fest International Great Silk Road Festival from 2021 (Shanghai Cooperation Organisation, 2019).

As the multi-faceted and active cooperation took place in SCO, SCO's member states are implying ever-larger control over the Asian continent and are shifting ahead to connect it economically, politically, and arguably, militarily (Rowden, 2018). Some scholars argue that SCO existence signifying that global order appears to be sliding from West to East. Moreover, following the European Union (EU) disunity and the United States' tendency to leave the global podium, there is a notion that "The West is breaking apart while the East is consolidating" (Putz, 2018). In the prevailing scenario, the notoriety of its name has blossom massively. Thus, some states are eager to focus on the organization and even willing to join it, making the parties who join the SCO forum table expanded. The parties involved in SCO are divided into three categorization: member states, observer states, and dialogue partners. At the time of this study's writing, the parties involved in SCO are 22 in total. See the picture below,

Figure. 1: SCO member, observer, dialogue partner states

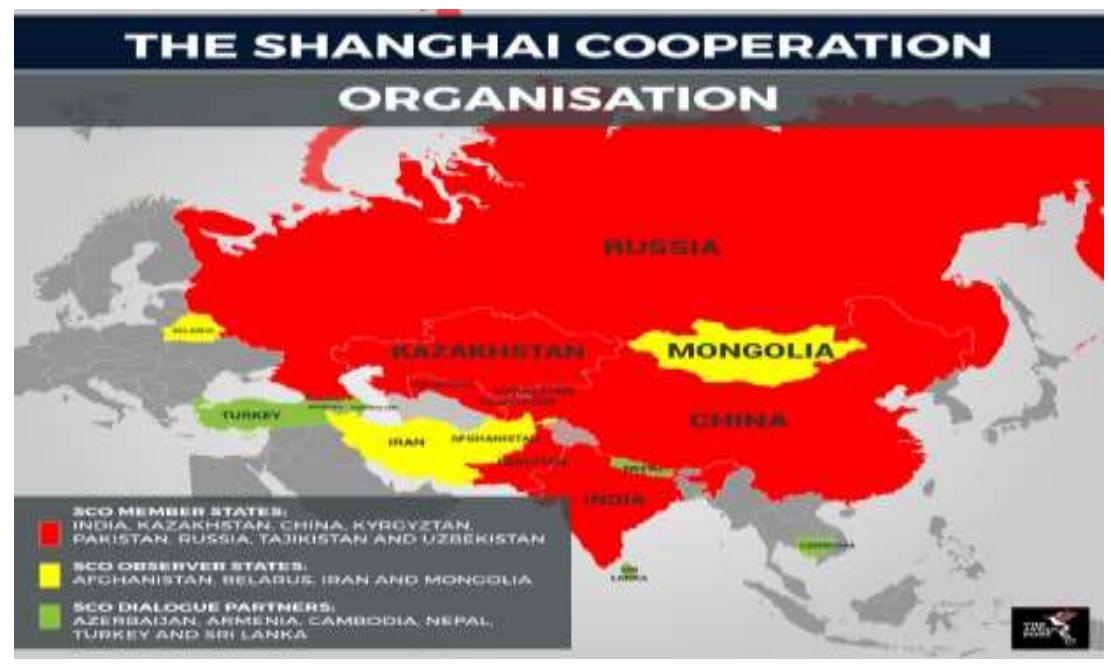

Source: The ASEAN Post (https://theaseanpost.com/article/shanghai-cooperation-organisation-the-rise$\underline{\text { east }}$ 
SCO is an eye-catching international organization for the state and an oft-used unit of analysis for International Relations academics. Following the spill-over of cooperation boundaries, the participation of some new-emerging powers (China, India, Iran, Pakistan, Russia, and Turkey), and the existing robust intimacy of its member states, SCO has been labeled as a successful regional organization and ostensibly stamped as an endowed-land for a plethora of analysts to harvest the fruit of scholarly writings.

Having in mind that SCO maturity and notoriety are increasing both in the political and scholarly realm, the prime impetus behind this study is the necessity to answer the question sound, "can SCO expand and be a supranational organization?".

\section{Theoretical Framework: SCO and Supranationalism}

The SCO's way of life (values, principles, mechanism) invites both praise and cursing. The organization's daily life also became the steppingstone of many commentaries. In this section, this study shed lights on the story of SCO that exist within International Relations studies, particularly within the scope of regionalism-related research. This section also illuminates the basic idea of supranationalism, considering that it serves as the core concept in this study.

\section{SCO in the Stream of International Relations Discussion}

SCO has worked as an essential catalyst for security, economic, and cultural integration in Central Asia. Resultantly, the notoriety of its name strengthens and further extended in International Relations studies. The literature installing SCO as the unit of analysis is enormous in scale and various in topic variety. Commonly, but not exclusively, scholars have spawned analysis towards SCO in four scopes of discussion; 1.) about SCO's origins and existing anatomy (organizational structure, rules, and norms); 2.) about its evolution, development, prospects, and opportunities; 3.) about its role in Central Asia's regional security; 4.) and about its blemishes and ailment.

For the first kind of issue, Lorena Di Placido's writings “Origins, Development, and Consolidation of the Shanghai Cooperation Organization after the Bishkek Summit" is one of the most relevant literature since it explains the issue in a comprehensive and coherent way. Regarding the second issue, two scholarly writings deserve to be mentioned: 1). The work of Khalid Rahman 
"The Shanghai Cooperation Organization: Prospects and Opportunities" whereby it has shed light on the possible bright opportunities and heavy duties of SCO in the future (Rahman, 2007); 2.) Rashid Alimov's paper "The Shanghai Cooperation Organisation: Its role and place in the development of Eurasia" by which it argues that SCO has been the key player for making the turning point of the nascent progressive shift toward better regional cooperation in Central Asia. Since SCO is firmly correlated with security-related discussion, numerous literatures found on the third type of issue. Two among other examples are Marc Lanteigne's works "In Media Res; The Development of the Shanghai Cooperation Organization as a Security Community" and Jeffrey Reeves' paper "the Shanghai Cooperation Organisation: A Tenable Provider of Security in Post2014 Central Asia?" (Reeves, 2014).

The last type of issue is the most exciting subject to be paid attention to. SCO has often been grappling with scholars' pessimism and cynicism, whether because of the existing actors inside the body or the generated performances. Mostly, following the involvement of Iran, India, Mongolia, and Pakistan, the critics are sourced from the group of United States' analysts (Bailes \& Dunay, 2007). Arguably, it is on account of the majority of United States' analysts posit SCO as the geopolitical equilibrium for their country (Cohen, 2006). The skeptical notion of belittling SCO's presence is echoed in various sounds. Many scholars choose to describe SCO as the Russian-Chinese's instrument to head-off the growing shadow of western states influence, particularly the United States, in Central Asia, thus making the Central Asian regional organization stamped as an anti-western bloc (Aris, 2009). Richard Weitz believes that SCO, since its founding, has substantially performed as a Chinese-Russian condominium, a multilateral stage for both great powers to manage their interest in the newly independent states of Central Asia (Weitz, 2008). Henry Plater-Zyberk and Andrew Monaghan argue that SCO would face considerable hindrance to expand its membership further because of the China-Russia's conflict of interest and the existing member states' reluctance to allow the entry of new candidates, which, they argue, might be a potential source of international liabilities and internal conflict within the organization (PlaterZyberk \& Monaghan, 2014).

On the premise of SCO's vision, Jean-Pierre Cabestan signifies a conflicting vision within the organization. The member states of SCO still embrace different goals and incompatible perspectives, thus making the organization filled with many uncertainties related to its operation and mission (Cabestan, 2013). One of the most eye-catching opinions in overthrowing SCO's 
dignity is what Thomas Ambrosio has in mind. Ambrosio argues that SCO establishment was the strategy for its member states' government to establish relevant policies for preserving their political power. This multilateral cooperation aims to defend themselves against regional democratic trends, which, on a particular occasion, considered as a menace for sustaining 'stability', high premium value for SCO (Ambrosio, 2008). Driving from the argument that SCO member states are not liberal democracies, critical judgment harbored to SCO that it is an 'autocrats club' (Wall, 2006). A club whereby a bunch of states enjoys the luxury of not having any critical demands from society for their lack of liberal democratic principles and poor human rights adherence (Tisdall, 2006).

Scholars have given various perspectives regarding to the SCO. Yet, to the researcher's knowledge, perspectives related to SCO and supranationalism still not gaining 'a most-talked about' status. This study aspires to enrich the color of those perspectives by creating a discussion juxtaposing SCO with supranationalism. A question of "Can SCO be supranational?" need an answer in the mid of SCO's rise. To have a proper way to shed light an argument, this study should provide some knowledge about the basic questions "what is the substance of supranationalism" and "what is the ticket of admission for an organization to be supranational?"

\section{Supranationalism at a Glance}

Lexico English Dictionary defines 'supranational' as an adjective, whether it belongs to an individual, group, or institution, which implies the prestige of "having power or influence that transcends national boundaries or governments" (Lexico, n.d.). Interpreted in parallel meaning yet different words distribution, Cambridge Dictionary delineates 'supranational' also as an adjective that signifies a subject's activity is "involving more than one country, or having power or authority that is greater than that of single countries" (Cambridge Dictionary, n.d.).

Janusz Ruszkowski's attempt to decipher supranationalism's meaning by considering linguistic deliberation deserves to be mentioned in this regard. Semantically, the Latin prefix 'supra' used in amalgam words should be translated not only as 'beyond' but also, or, most suitable perhaps, as 'above' as contradictive in meaning to the prefix sub designating 'under' or 'below'. Therefore, Ruszkowski arrives at an outcome that the notion of supranationalism projects an image whereby certain actors stand above nations and sometimes above the states (Ruszkowski, 2009). 'Ism' means "a distinctive practice, system, or philosophy, typically a political ideology or an 
artistic movement" (Lexico b, n.d.). Therefore, the three last alphabets 'ism' implies nothing other than, that 'supranationalism' is an ideology. Thus, it is feasible that many scholars, such as Charles de Gaulle, Paul Close, Emiko Ohki-Close, labeled supranationalism as a stream of doctrine (de Gaulle 1994, p. 30; Close \& Ohki-Close, 1999, p. 224).

Other fundamental questions subsequently appear; how supranationalism manifests itself into a concrete entity? Supranationalism performs diversely, making it possess more than one face. On one side, supranationalism is a stage of international cooperation, while on the other side, it is a model of institutional structure present in International Relations, or, in a narrow view, in European studies. It also serves as a means of cooperation, or integration rather, locating international interactions on the supranational level (Ruszkowski, 2009).

A very bright example of supranationalism can be identified in the European regionalism. Within the EU, the member states acquire collective actions by delegating authority to the collective institutions to diminish transactions and enforcement costs (Levy, 2017). The body's commission possesses the power to negotiate on behalf of the Union in its trade and other external relations (Goebel, 2013). Hence, National-level decision making is somewhat ambivalent and insignificant for their member states to deal with these affairs (Menon \& Weatherill, 2007). The EU's legal system, which stemmed from the 1958 Treaty of Rome and its subsequent amendments (the 1987 Single European Act and the 1993 Treaty on European Union), also became an eyecatching manifestation supranationalism. It functions even if it has not been integrated into the domestic law, thus making it has 'direct effect' in national jurisdictions and also supremacy over conflicting domestic laws (Garret, 1995).

Another question is what is the distinguishing quality of supranational organization compared to other modes of global governance, in this sense, intergovernmental organization? Given that international cooperation is initiated by, or exists based on the desire of, states, it is intentionally and voluntarily created (as a result of tests, experiments, and research) by national states (Ruszkowski, 2009). Despite having a parallel purpose, to bridge international cooperation, the distinguishing character of a supranational organization and intergovernmental organization lies on the level of superiority.

Basically, international organizations that intergovernmental in nature are based on 'sovereign equality' and 'non-intervention in domestic affairs' principles. Indeed, sovereignty may be more or less restricted, but its member states never transfer their sovereignty entirely. Every 
treaty or regulation created by the intergovernmental organization is 'international' in the sense that they cannot bind the member states legally nor operate directly against the individual subjects of the member states. The intergovernmental organization does not acquire a commanding role, and its decisions are not executive. Although it can take exceptionally binding decisions, the voting procedure shows the members' sovereignty, whether unanimity of all or unanimity of certain privileged members exists. All these organizations are no more than loose associations of sovereign states, which have their highest form in the type of union of states (Kunz, 1952).

A different narration would appear on the supranational organization. The terms like 'global' or 'international' are frequently used in reference to the relations between multiple states. In another dimension, the term "supranational" seems to indicate that the state connections are more integrative or encompassing (Culcasi, 2011). This notion occurred because when the states jump into the pool of supranationalism, they are willing to transfer or to share their political authority, or even sovereignty, to a supranational set of institutions which stands over and above themselves, their institutions, and citizens (Kahler \& Lake, 2009, p. 6; Close, 2000, p. 14; Close \& Ohki-Close, 1999, p. 224; Shaw, 1996, p. 12). Once the states decide to blend in supranationalism, every consensus (regulations, treaty, common interests), set up by supranationalism is deemed to prevail among and bind them (Mason, 1955). Supranational denotes that a shared system of rules, norms, principles, and codes of conduct are inducted, internally organized, and taken as an obligation by involving actors (Trondal, 2007). This makes the discussion of supranationalism always related to the notion of sovereignty deficit.

Notwithstanding the decrease of sovereignty, the member states of supranationalism still have power. Nevertheless, they must allocate this power with other actors. Furthermore, decisions tend to be created majority-votes system. Hence, the possibility for a member state to be forced by the other to agree upon a decision against its desire does exist. However, since the member states participate voluntarily, being subject to the supranational government only so far as they decide to remain members (Leal-Arcas, 2007).

Supranationalism' is not only referring to an entity that stands above states or nations, but also to a program overcoming a high sense of nationalism of its member states. Supranationalism abolishes a specific breed of nationalism of its member (e.g. German, French, British nationalism), one among other means is, by replacing it with a newly-minted sense of supranationalism (e.g. EU nationalism) (Mamadouh, 1998). Considering that supranationalism is a doctrine that stands in the 
opposite position to nationalism, it is diametrically opposing ultranationalism. The prefix 'ultra-' infers "a person who has extreme political or religious opinions" (Cambridge Dictionary b, n.d.). Thus, ultranationalists are extreme nationalists, and would presumably be extremely hostile to supranationalism, supranationalists, supranational institutions, supranational regional regimes (Close \& Ohki-Close, 1999). To this fact, efforts to make supranationalism come to fruition would reaching a nadir if the member states are tightly embracing ultranationalism.

From the elaboration above, two points have been extracted. The first point, an international organization's struggle to become supranational in nature, would face blatant stonewalling if and when its member states are still reluctant to have sovereignty transfer. The member states remain loath to make the organization stands above and binds them. The states having extreme adherence to sovereignty would eventually portray the idea of supranationalism as a threat that may obstruct their quest for power and interests. The second point, a dense shadow of ultranationalism embedded within a state, whether government or society, would make supranationalism atmosphere unacceptable. Bearing in mind that supranationalism eliminates, not entirely but partially, the sense of nationalism of its member states, the ultranationalist state would become a fundamental barrier for an organizations' attempt to transform into a supranational organization.

The previous explanation makes it abundantly clear that the implant of supranationalism character within an organization would make the existing states placed at a lower level. SCO is now intergovernmental in nature. Since it acts only as a 'bridge' of negotiation, its degree of authority is less than its member states. Thus, it merely acts as a platform for its member states to put forward and to actualize their interest. By seeing the present condition, is there any possibility for SCO to be supranational in its existence? Can it cajole its member states to transferring their sovereignty and diminishing their sense of nationalism? Or in otherwise, do the overemphasis on sovereignty and nationalism by its member states could be the reasons that make SCO is impotent to be supranational?

\section{Research Method}

This study relies on qualitative research and the library research method. Having in mind that the qualitative research method allows us to have an in-depth analysis of attitudes, events, and social phenomenon (McCusker \& Gunaydin, 2015), this study comprehends the character, development, 
and social dynamics within SCO thoroughly to obtain relevant knowledge that can support the existing argument of the author. This study also depends on the library research techniques to acquire the existing analysis and data from secondary resources, such as books, journals, websites, government reports, and newspapers (Raco, 2018). The discovery of some literature that is parallel with the topic helps this study make a fact-based argument and confirm its distinguishing quality from previously published literature.

\section{Barriers for SCO to Gain Supranationalism}

The students of International Relations might propose a skeptical argument that SCO will never be supranational. Still, this prediction would seem premature and not materialized if the question "why" being ignored from the argument. The objective of this study is to provide the answer of "why" by suggesting that SCO is impotent to be supranational because of three principle barriers; 1) over-adherence upon sovereignty, 2) hegemonic quest of power with increasing nationalism.

\section{SCO and its Member States; the Agent and the Adorer of Sovereignty}

The founding members created SCO in order to allow them to harvest the fruits of sovereignty without significant obstacles. SCO is expected to protect and to give tribute to the 1648 Westphalian product; the sovereignty of the state's border. As of its early formation, SCO was firmly entrenched in the process of safeguarding the border principles of its member states. It was designed to solve its member states' border-related dispute, a heritage of Soviet Union dissolution. It can be suggested that SCO was the spillover effect of the early fix states cooperation, which is specifically dedicated to deal with border issues. Without the border-related agreement among the

five states, there will be no regionalization that will beget SCO. The fourth paragraph of The Declaration on the Establishment of the SCO deserved to be mentioned to shed light on this argument:

"..... the two agreements signed by the five head of states ..... in Shanghai in 1996 and in Moscow in 1997, on confidence building-building in the military sphere in border areas and on mutual reduction of military forces in border the areas, ..... have made important contribution to preserving regional and world peace, security, and stability, greatly enriched contemporary diplomatic and 
regional cooperation practices....." (The Declaration on the Establishment of the Shanghai Cooperation Organisation, n.d.).

Albeit SCO is regarded as a successful regional organization, it still cannot escape from several skirmishes on border misunderstanding between its member states; take into account how the escalation of the Kyrgyz-Uzbek border issue took place in 2016 and the emergence of border clash between China and India happen in June 2020. Moreover, despite demarcation in unison, border crossings are difficult throughout SCO's region, reducing regional trade effectiveness and causing tension. For the sake of security, limiting cross-border movements have often been done in SCO (International Crisis Group, 2002). It has been widely acknowledged that border-related issues among nation-states are sovereignty matters. The blatant devotion of SCO on border issue signifies how sovereignty is an utmost important element for it.

The prime objective of a regional organization is to initiate a complete sustainable regional integration within its region. In its highest form, a mature integration is when the region able to abolish tight restrictions on the state's borders, or in other words, it is borderless. Having in mind that it wants to achieve total integration, a regional organization would be eager to attain supranationalism leverage. It is a way that could rule out any obstacles to gain the 'imagine' integration, which is usually posed by a state's sovereignty. In a simple manner, when a regional organization seeks to have thorough and complete integration, it would have greater reason to be the one who manages to accomplish it through supranationalism means.

The EU becomes a standard reference for an excellent supranational organization. Learning from the dark past of the world war, the EU became a regional organization that wanted a total integration exist within its region. By being encouraged to get hold of its dream, the EU tried to be a supranational one. Nowadays, it has been a successful example in the history of regional integration since it can acquire a total integration, whereby the state's border control is abolished. The 1985 Schengen Agreement has been the catalyst for decreasing European states' adherence toward their border issues as it aims to support the free movement of people, goods, services, and money across the region. A way that has provided an opportunity for Europe to have an exceptional level of integration compared to other regions around the globe.

In an extremely antithetical position with the EU, SCO is absent of the desire to offer total integration for its region. Its foundation is built on its member states' tendency to uphold their 
border status and sovereignty. When SCO bereft of willingness to attain total integration, then it also bereft of basis to be a supranational one.

It may not be far-fetched to suggest whether SCO or its member states are the adorers of sovereignty. Since supranationalism would only exist when a regional organization seeks to have a total integration through the abolition of border status and sovereignty limitation, there will be no hope for supranationalism to be practiced by SCO. Moreover, overwhelming devotion to sovereignty will make SCO member states reluctant to make the organization stands above them, whereas supranationalism would only make the organization behave so.

United Kingdom (UK) withdrawal from the EU might be the best-supporting evidence for picturing how the follower of sovereignty unable to go hand in hand with supranationalism. On 31 January 2020, the UK has officially withdrawn from being a member of the EU. There are three general reasons why either UK's government or civil society believes that their country must leave the EU; 1.) decisions about the UK should be taken in the UK; 2.) The UK should regain control over immigration and its own borders; 3.) The EU can expand its power over the UK. The motives behind the UK's withdrawal signifies that the country now begins to put sovereignty above all. Since that, they portrayed the EU as an adverse regional organization. To this extent, considering that a supranational organization requires the transfer of sovereignty, how could it be possible for SCO to become supranational if SCO itself and all of its member states are since they existed in international society's realm, the UK-now?

\section{SCO as a Playground for Stubborn Hegemonies with Bold Nationalism}

Various notions arise from scholarly discussion pointing to how SCO became the playground for powerful countries to advocate their interests in Central Asia's middle-power countries. They are China and Russia, who have overlapping and diverging interests in the region. Since its establishment in 2001, SCO has substantially functioned as a Chinese-Russian condominium (Weitz, 2008). This effect is particularly striking in the case of China and Russia's competition to promote their own-designed strategic cooperation framework; The Eurasian Economic Union (EAEU) on behalf of Russia and the One Belt One Road (OBOR) initiative on China's side. The application of the EAEU integration process and OBOR strategy are originally arranged to strengthen the regional influence of Beijing and Moscow, respectively (Alimov, 2018). Several 
scholars argue that the two countries economic strategy are contradictive with each other; thus, any attempt to synchronize the two projects is unattainable (Marantidou \& Cossa, 2014).

The conflicting interest of both powerful countries also manifested in energy-related cooperation within SCO. Even though China and Russia have a parallel commitment to level up Central Asian oil and gas production, Russia has been persistent in maintaining its control over these resources and also the region's transportation infrastructures. In a contradictory position with Russia to gain wider control, China wants to exercise direct supervision over regional energy assets. Another contrasting interest between the two countries is about the SCO mechanism in managing its energy-related cooperation. Moscow possesses a great desire to build a unified multilateral energy bloc for SCO, allowing its state-run energy companies to dominate. On the other side, Beijing pursues bilateral deals that would enable them to redirect Central Asian oil and gas eastward rather than into Russia. This cross-cutting interest of Beijing and Moscow has made SCO getting little room for maximizing its potential in the energy realm (Weitz, 2008).

Another China and Russia's competition of influence entrenched in their struggle to determine SCO's security dimension. Both countries possess different orientations for what role SCO should hold in maintaining Central Asia's security. Beijing hopes that SCO could become a device to avert future Tiananmen-like rebellions. Differently, Moscow wants SCO to be a catalyst to abolish Russia's possibility to fight another Chechnya-style counterinsurgency operation. Furthermore, Russia sought to make SCO an intact military institution to transform SCO into a formal anti-Western alliance and strengthen its influence over SCO's member states national militaries. Still, Russia's attempt in doing so has been hampered by China's different passion who prefer to make SCO be a quasi-military alliance (Weitz, 2008).

China favors an organization whose central purpose is internal security (anti-terrorism) and economic cooperation instead of politicized anti-Americanism (Weitz, 2008). This is due to China's approach to SCO is driven entirely by domestic security, energy, and commercial interests. Beijing's concern for domestic security is because it has long been worried that instability and Muslim turbulence on its borders with Central Asian countries could spark Islamic separatist movements in the Xinjiang region (Stronski \& Sokolsky, 2020). Furthermore, in economic-related concern, China is keen to make SCO a podium to have greater economic leverage and promote its soft power in the region (Lanteigne, 2018). This contest of the two hegemonies in deciding the face and essence of SCO can be best described by the words of Stephen Blank "China blocked 
Russian efforts to convert the organization into a military alliance, and Russia is now blocking Chinese efforts to convert the organization into a trade bloc" (Blank, 2013).

China and Russia's existence more likely to become a threat rather than a boon for SCO. Both countries' contributions to the organization are significant, yet, they have not been what many were hoping for. The plethora of Beijing and Moscow's appearance in SCO signify only their competition to hegemonize the region. This atmosphere reflects that China and Russia are unable to put aside their self-interest for the goodwill of SCO to acquire' supranational' evolution.

Furthermore, China and Russia are the hegemonic power with a high sense of nationalism, thus adding more principles barrier for SCO to pave its road to 'supranationalism'. It has been widely recognized that Xi Jinping administration (2012-present) has painstakingly obvious to show a turn towards nationalism. After the new Politburo committee was announced, two weeks later, Xi pronounced his "China Dream" policy, signed that he aimed to accomplish "the great renaissance of the Chinese nation" (Gore, 2016). To this extent, nationalism is obviously acting as an instrument to boost the Chinese Communist Party's (CCP) legitimacy to rule (French, 2015; Rosenfeld, 2016). As the consequence, "Rising nationalism" has been a dominant and eye-catching meme in the discussion of China's material power development since the early 1990s (Johnston, 2016). Shreds of evidence often appear related to China's rising nationalism. One case that deserves to be mentioned in this regard is China's rising aggressiveness in the South China Sea, which led to the growing tension in Southeast Asia.

China's submission of a map with the nine-dash line to the UN in 2009, continuous military actions, and unending sea resources exploration became the catalyst for the rising tension in the South China Sea. Nationalism has often been regarded as a groundwork for China's rising assertiveness in this area of water. At the time following the decision of the Permanent Court of Arbitration to turn down China's claims in the South China Sea, China's supporters turned to nationalism to elaborate the harsh Chinese response to the ruling (Gore, 2016). International media also echoed the argument that nationalism has become the key to drives China's foreign policy in the South China Sea.

On the other side, Russia's nationalism is as high as China. If China's nationalism invited trouble in the South China Sea, Russia's nationalism has summoned conflict in Crimea. Following the internal Ukrainian Crisis, Russia invaded and annexed Crimea in March 2014. It was an attempt to reclaim Russia's loss of influence in Ukraine after Pro-Russia Ukrainian president Viktor 
Yanukovych been toppled. Some observers believe that Russia's annexation is driven by Putin, who is a 'nationalist leader' (Hale, 2014). Since attaining power in 2000, Putin has successfully brought high economic growth and political and individual rights for Russia. Yet, after the economic curtail which led to Russian mass protests in 2012, Putin changed his strategies, put serious concern on "stirring up old-school anti-Western paranoia and imperial-style Russian nationalism" (Fisher, 2014). With respect to it, nationalist ideology and nationalist organizations are the prominent political instruments to build supports for the government and to consolidate power under the Putin administration (Strzelecki, 2017).

In Crimea, Russian are the majority ethnic. Therefore, Russian nationalists look at Ukraine as an undeniable part of Russia. Sponsoring the rebels and saving Ukraine became a manifestation of national pride for them. It is also a way to assert Russia's defiance of the West (Fisher, 2014). Thus, Henry E. Hale implies that "Crimea hits the "sweet spot" for Russian nationalism (Hale, 2014).

To further portray how bold China and Russia's nationalism is, a report on Resource Nationalism Index (RNI) released by Verist Maplecroft in 2019 is worthy of being mentioned.

Figure 2: Resource Nationalism Index 2019

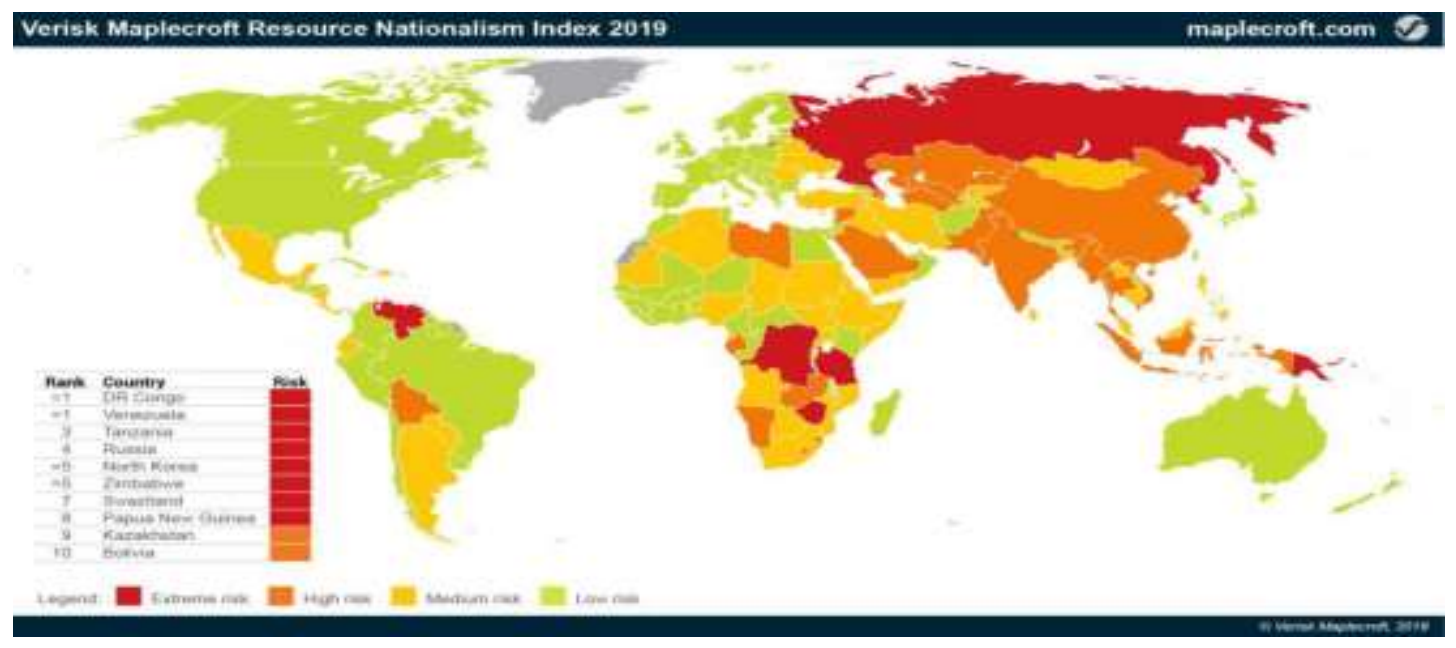

Source: Verisk Maplecroft (http://www.mining.com/30-countries-face-higher-resource-nationalism-risk-report/)

Resource nationalism signifies a government's exercise to attain higher control or value from its natural resources (Sainsbury, 2018). The struggle by states to gain benefits from the control and ownership of natural resources within their area of authority is not a new phenomenon. 
It has a long history that started in the mid-twentieth century. To this day, resource nationalism is a common and widespread state's policy related to energy supply (Pryke, 2017). On its highest level, nationalism resources can influence countries to adopt various approaches that may increase their access to natural resources in other countries (Ward, 2009). The RNI seeks to measure the level of expropriation risk, the imposition of a very strict fiscal regulation, and the burden for companies to source services and goods from local providers (Mining.com, 2019). The picture above highlights that Russia was marked as a country with an 'extreme risk' condition in RNI rate. Meanwhile, China is in a 'high risk' category. This finding then explains how nationalism indeed has taken control over Beijing and Moscow.

China and Russia's unbroken conflict of interest within the SCO body and high sense of nationalism illustrated by their aggressive action on other countries' territory and level of resource nationalism strengthen the indication that they are the hegemonies with strict adherence to nationalism. The utmost decisive requirement for an organization to be supranational is their members' willingness to have sovereignty transfer, limit their nationalism, and abolish their interest to hegemonize. Take into account the EU as the most successful supranational organization. Their member states are not hesitant to hand over some part of their sovereignty the Commission of the body, who has the ability to make some decisions that affecting its member states' domestic life. In the case of nationalism with hegemonic interest, EU member states are all lack, or even absent, of that sense, since they had enough with the occurrence of Wars. Having in mind that the two most authoritative members of SCO, China, and Russia, are the countries who possess the eagerness to hegemonize whether the organization or its counterparts and to prioritize their nationalism, SCO will be a supranational organization only if Russia and China have the same fate as Germany after the end of World War II - defeated by other power and simultaneously lost its hegemonic symptoms. If not so, SCO might be a supranational one only 'when the hell freezes over'.

\section{Conclusion}

After successfully breeding various kinds of cooperation in multi-facet fields, SCO has attracted many other countries' eagerness to join its membership. Nonetheless, the broad scope of cooperation and the accession of some new members may still be an insufficient basis for us to hope that SCO will become a supranational organization in the future. A supranationalism-based 
organization requires its member states to diminish their nationalism and to transfer a particular degree of their sovereignty to the organization. This path is the admission ticket for the organization to run its role as a supranationalism manifestation. Unfortunately, SCO is bereft of the ability to obtain this ticket. 'Guarding its member states sovereignty' is the cornerstone of SCO' establishment, thus making the organization is the agent of sovereignty and its member states, who create the organization, are the devotee of sovereignty itself. The existence of China and Russia's competition of influence is crystal clear. Their contest to attain power has been driven by their striking nationalism. By considering this condition, SCO will be struggling to death to pave its path to supranationalism since its member states resistant to transfer their sovereignty and diminish their nationalism.

\section{References}

Akram, K. T. (2020, April 28). Article by the Executive Director, Center for Global \& Strategic Studies of Pakistan Khalid Taimur Akram on the economic potential of the SCO. Retrieved from Shanghai Cooperation Organization: http://eng.sectsco.org/news/20200428/644757.html

Alimov, R. (2018). The Shanghai Cooperation Organisation: Its role and place in the development of Eurasia. Journal of Eurasian Studies, 9, 114-124. Retrieved from https://doi.org/10.1016/j.euras.2018.08.001

Ambrosio, T. (2008). 'Catching the Shanghai Spirit': How the Shanghai Cooperation Organization Promotes Authoritarian Norms in Central Asian. Europe-Asia Studies, 60(8), 1321-1344. Retrieved from https://www.jstor.org/stable/20451609

Aris, S. (2009). The Shanghai Cooperation Organisation: 'Tackling the Three Evils', A Regional Response to Non-Traditional Security Challenges or an Anti-Western Bloc? Europe-Asia Studies, 61(3), 457-482. Retrieved from https://www.jstor.org/stable/27752254

Bailes, A. J., \& Dunay, P. (2007). The Shanghai Cooperation Organization as a regional security institution. In A. J. Bailes, P. Dunay, P. Guang, \& M. Troitskiy, The Shanghai Cooperation Organization. Stockholm International Peace Research Institute. Retrieved from https://www.jstor.org/stable/resrep19208.7

Blank, S. (2013). Making Sense of the Shanghai Cooperation Organization. Georgetown Journal of International Affairs, 14(2), 39-49. Retrieved from https://www.jstor.org/stable/43134410

Cabestan, J.-P. (2013). The Shanghai Cooperation Organization, Central Asia, and the Great Powers, an Introduction; One Bed, Different Dreams? Asian Survey, 53(3), 423-435. Retrieved from https://www.jstor.org/stable/pdf/10.1525/as.2013.53.3.423.pdf?refreqid=excelsior\%3Af4 7236f3eb3f50284d65ed1931273b5b

Cambridge Dictionary b. (n.d.). Ultra. Retrieved April 21, 2020, from https://dictionary.cambridge.org/dictionary/english/ultra 
Cambridge Dictionary. (n.d.). Supranational. Retrieved April 20, 2020, from https://dictionary.cambridge.org/dictionary/english/supranational

Close, Paul. (2000). The Legacy of Supranationalism. Palgrave Macmillan; London. Available at: https://booksc.xyz/dl/21449580/d73611

Close, P., \& Ohki-Close, E. (1999). Supranationalism in the New World Order; Global Process Reviewed. London: Palgrave Macmillan. Retrieved from https://bok.cc/dl/2686297/e2a106

Cohen, A. (2006). The US Challenge at the Shanghai Summit. The Heritage Foundation. Retrieved from The Heritage Foundation: https://www.heritage.org/europe/report/the-uschallenge-the-shanghai-summit

Culcasi, K. (2011). Cartographies of Supranationalism; Creating and silencing territories in the 'Homeland Arabic'. Political Geography, 30, 417-428. Retrieved from https://booksc.xyz/dl/17218087/abe09e

de Gaulle, Charles. (1994). A concert of European states. In Nelsen, F. Brent \& Stubb, Alexander (Eds.), The European Union; Readings on the Theory and Practice of European Integration (25-41). Lynne Rienner Publishers, Inc. Available at: https://bok.cc/dl/2675533/eff5fb

de Haas, M., \& der Putten, F.-P. v. (2007). The Shanghai Cooperation Organisation Towards a full-grown security alliance? Den Haag: Nederlands Instituut voor Internationale Betrekkingen Clingendael. Retrieved from https://www.clingendael.org/sites/default/files/201602/20071100_cscp_security_paper_3.pdf

Di Placido, L. (2007). Origins, Development, and Consolidation of the Shanghai Cooperation Organization after the Bishkek Summit. Connections, 6(3), 62-81. Retrieved from https://www.jstor.org/stable/10.2307/26323299

Fisher, M. (2014, September 30). The Vox. Retrieved June 16, 2020, from Everything you need to know about the Ukraine crisis: https://www.vox.com/2014/9/3/18088560/ukraineeverything-you-need-to-know

French, Howard, W. (2015, July 28). What's behind Beijing's drive to control the South China Sea?. The Guardian. Accessed on: 15 June 2020. Available at: https://www.theguardian.com/world/2015/jul/28/whats-behind-beijings-drive-controlsouth-china-sea-hainan

Garret, G. (1995). The Politics of Legal Integration in the European Union. International Organization, 49(1), 171-181. Retrieved from https://www.jstor.org/stable/pdf/2706870.pdf?refreqid=excelsior\%3A57bc4aebd6eba124 e19fb9770f22f8c6

Goebel, R. J. (2013). Supranational? Federal? Intergovernmental? The Governmental Structure of the European Union after the Treaty of Lisbon. Columbia Journal of European Law, 77. Retrieved from https://ir.lawnet.fordham.edu/faculty_scholarship/577

Gore, B. (2016, September 3). The Appeal of Nationalism: Explaining China's Assertiveness in the South China Sea. Retrieved June 15, 2020, from Young China Watchers: https://www.youngchinawatchers.com/the-appeal-of-nationalism-explaining-chinasassertiveness-in-the-south-china-sea/

Guang, P. (2011). The SCO's Success in Security Architecture. In R. Huisken, The Architecture of Security in Asia-Pacific (pp. 33-43). Canberra: ANU Press. 
Hale, H. E. (2014, August 29). Russian nationalism and the logic of the Kremlin's actions on Ukraine. Retrieved June 16, 2020, from The Guardian: https://www.theguardian.com/world/2014/aug/29/russian-nationalism-kremlin-actionsukraine

Haq, N., \& Mughal, F. A. (2007). Shanghai Cooperation Organisation (2001-2006). 1. Retrieved from

http://globalsummitryproject.com.s197331.gridserver.com/archive/shanghai_cooperation _organization1/ipripak.org/factfiles/ff85.pdf

International Crisis Group. (2002). Central Asia: Border Disputes and Potential Conflict. ICG Asia Report No. 33. Retrieved from https://d2071andvip0wj.cloudfront.net/33-centralasia-border-disputes-and-conflict-potential.pdf

Johnston, A. I. (2016). Is Chinese Nationalism Rising? International Security, 4(3), 7-43. Retrieved from https://www.belfercenter.org/sites/default/files/files/publication/isec_a_00265.pdf

Kahler, Miles., \& Lake, David, A. (2009). "Economic Integration and Global Governance: Why So Little Supranationalism? ". In The Politics of Global Regulation, edited by Walter Mattli and Ngaire Woods. Princeton: Princeton University Press. Available at: https://bok.cc/dl/1185662/6c $7 \mathrm{bc} 4$

Kunz, J. L. (1952). Supra-National Organs. The American Journal of International Law, 46(4), 690-698. Retrieved from https://booksc.xyz/dl/50348971/f655fd

Lanteigne, M. (2018). Russia, China, and the Shanghai Cooperation Organization: Diverging Security Interest and the 'Crimea Effect'. In E. W. Rowe, \& H. Blakkisrud, Russia's Turn to the East: Domestic Policymaking and Regional Cooperation. Basingstoke: Springer Nature. Retrieved from https://library.oapen.org/bitstream/id/fd27c7c5-368b-4e51-ac02e22072893a8d/1001859.pdf\#page $=130$

Leal-Arcas, R. (2007). Theories of Supranationalism in the EU. The Journal of Law in Society, 8(1), 83-113. Retrieved from https://papers.ssrn.com/sol3/papers.cfm?abstract_id=995748

Lexico b. (n.d.). Ism. Retrieved April 20, 2020, from https://www.lexico.com/definition/ism

Lexico. (n.d.). Supranational. Retrieved April 20, 2020, from https://www.lexico.com/definition/supranational

Levy, E. Richard. (2017). The law and economics of supranationalism: the European Union and the subsidiarity principle in collective action perspective. European Journal of Law and Economics, 43, 441-473. Available at: https://doi.org/10.1007/s10657-015-9508-X

Mamadouh, V. (1998). Supranationalism in the European Union: what about multilingualism? World Political Map Conference on Nationalism and Identities in a Globalized World. The Institutional Repository of the University of Amsterdam. Retrieved from http://citeseerx.ist.psu.edu/viewdoc/download?doi=10.1.1.918.2142\&rep=rep1\&type=pdf

Marantidou, V., \& Cossa, R. A. (2014, October 1). China and Russia's Great Game in Central Asia. Retrieved May 12, 2020, from The National Interest: https://nationalinterest.org/blog/the-buzz/china-russias-great-game-central-asia-11385

Mason, Henry, L. (1955). The European Coal and Steel Community; Experiment in Supranationalism. Martinus Nijboff; The Hague. Available at: https://bok.cc/dl/2243812/acb91c 
McCusker, K., \& Gunaydin, S. (2015). Research using qualitative, quantitative or mixed methods and choice based on the research. Perfusion, 30(7), 537-542.

doi:10.1177/0267659114559116

Menon, A., \& Weatherill, S. (2007). Democratic Politics in a Globalising World:

Supranationalism and Legitimacy in the European Union. London School of Economics and Political Science. Retrieved from http://www.lse.ac.uk/law/working-paperseries/2007-08/WPS13-2007MenonandWeatherill.pdf

Menon, R., \& Spruyt, H. (1999). The Limits of Neorealism; Understanding Security in Central Asia. Review of International Studies, 25(1), 87-105. Retrieved from https://booksc.xyz/dl/53701872/20d615

Mining.com. (2019, March 22). 30 countries face higher resource nationalism risk - report. Retrieved June 17, 2020, from http://www.mining.com/30-countries-face-higherresource-nationalism-risk-report/

Plater-Zyberk, H., \& Monaghan, A. (2014). Strategic Implication of the Evolving Shanghai Cooperation Organization. Strategic Studies Institute, US Army War College. Retrieved from https://www.jstor.org/stable/resrep11392

Pryke, S. (2017). Explaining Resources Nationalism. Global Policy, 8(4), 474-482. Retrieved from https://www.globalpolicyjournal.com/articles/global-commons-andenvironment/explaining-resource-nationalism

Putz, C. (2018, June 12). A West in Crisis, an East Rising? Comparing the G7 and the SCO. Retrieved July 1, 2020, from The Diplomat: https://thediplomat.com/2018/06/a-west-incrisis-an-east-rising-comparing-the-g7-and-the-sco/

Raco, J. (2018). Metode Penelitian Kualitatif; Jenis, Karakteristik dan Keunggulannya. Jakarta: Grasindo.

Rahman, K. (2007). The Shanghai Cooperation Organization: prospect and Opportunities. Policy Perspectives, 4(1), 129-136. Retrieved from https://www.jstor.org./stable/42909167

Reeves, J. (2014). The Shanghai Cooperation Organisation: A Tenable Provider pf Security in post-2014 Central Asia? Daniel K. Inouye Asia-Pacific Center for Security Studies. Retrieved from https://www.jstor.org/stable/resrep14028

Rosenfeld, Everett. (2016, July 11). South China Sea: Beijing watches as The Hague ruling looms. CNBC. Accessed 15 June 2020. Available at: https://www.cnbc.com/2016/07/11/south-china-sea-beijing-watches-as-the-hague-rulinglooms.html

Rowden, R. (2018). The rise and rise of the Shanghai Cooperation Organization. Sheffield Political Economy Research Institute (SPERI). Retrieved from http://speri.dept.shef.ac.uk/wp-content/uploads/2018/11/SPERI-GPE-Brief-No.-11-Therise-and-rise-of-the-Shanghai-Cooperation-Organisation.pdf

Ruszkowski, J. (2009). Supranationalism between nation-state and international cooperation. Journal of Public Administration and Policy Research, 1(1), 004-010. Retrieved from http://citeseerx.ist.psu.edu/viewdoc/download?doi=10.1.1.428.6076\&rep=rep1\&type=pdf

Sainsbury, P. (2018, May 21). What is resource nationalism? Retrieved June 17, 2020, from Material Risk: https://materials-risk.com/what-is-resource-nationalism/

Shanghai Cooperation Organisation. (2019, May 5). Press release on the results of the 16th meeting of the ministers of culture of the Shanghai Cooperation Organization's memberstates. Retrieved May 11, 2020, from http://eng.sectsco.org/for_media/20190515/538789.html 
Shanghai Cooperation Organisation. (n.d.). Retrieved June 6, 2020, from The Declaration of the Establishment of the Shanghai Cooperation Organisation: http://eng.sectsco.org/load/193054/\#: :text=The\%20Shanghai\%20Cooperation\%20Organ ization\%20has,in\%20Shanghai\%20and\%20Moscow\%20respectively.

Shaw, Jo. (1996). Law of the European Union. Macmillan Press; London. Available at: https://bok.cc/dl/2672171/c5ff4b

Stronski, P., \& Sokolsky, R. (2020). Multipolarity in Practice: Understanding Russia's Engagement with Regional Institutions. Carnegie Endowment for International Peace. Retrieved from https://carnegieendowment.org/files/Stronski_Sokolsky_Multipolarity_final.pdf

Strzelecki, J. (2017). Russian nationalism three years after the annexation of Crimea. Centre for Eastern Studies (OSW). Retrieved from https://www.osw.waw.pl/en/publikacje/oswcommentary/2017-08-08/russian-nationalism-three-years-after-annexation-crimea

The Declaration on the Establishment of the Shanghai Cooperation Organisation. (n.d.). Retrieved June 6, 2020, from Shanghai Cooperation Organisation: http://eng.sectsco.org/load/193054/\#: :text=The\%20Shanghai\%20Cooperation\%20Organ ization\%20has,in\%20Shanghai\%20and\%20Moscow\%20respectively.

Tisdall, S. (2006, June 6). Irresistible Rise of the Dictators Club. Retrieved May 31, 2020, from The Guardian: https://www.theguardian.com/commentisfree/2006/jun/06/world.comment

Trondal, J. (2007). Is the European Commission a 'Hothouse' for Supranationalism? Exploring Actor-Level Supranationalism. Journal of Common Market Studies, 45(12), 1111-1133. Retrieved from https://www.researchgate.net/publication/4991712_Is_the_European_Commission_a_'Ho thouse'_for_Supranationalism_Exploring_Actor-Level_Supranationalism

Wall, D. (2006, June 15). The Shanghai Cooperation Organisation: Uneasy Amity. Retrieved May 31, 2020, from Open Democracy: https://www.opendemocracy.net/en/shanghai_cooperation_3653jsp/

Ward, H. (2009). Resource nationalism and sustainable development; a primer and key issues. International Institute for Environment and Development (IIED). Retrieved from https://pubs.iied.org/pdfs/G02507.pdf

Weitz, R. (2008). China-Russia Security Relations: Strategic Parallelism without Partnership or Passion? Strategic Studies Institute, US Army War College. Retrieved from https://www.jstor.org/stable/resrep11963.11 